\title{
Parathyroid carcinoma: A rare cause of hyperparathyroidism in a geriatric patient underwent orthopedic surgery
}

\author{
Paratiroid Karsinomu: Ortopedik cerrahi uygulanan geriatrik hastada hiperparatiroidinin nadir bir nedeni
}

\author{
Mehmet Tolga Kafadar ${ }^{1}$, Bilal Kabalak², Metin Yalçın ${ }^{1}$, Emine Zeynep Tarini ${ }^{3}$
}

\begin{abstract}
Parathyroid cancer is a rarely encountered disease which may accompany with hyperparathyroidism. It is hard to diagnose the disease before surgical treatment and to differentiate it completely from adenoma. The treatment of parathyroid cancer includes removal of the tumor and the thyroid lobe completely on the same side through neck exploration and removing the lymph nodes at the neighborhoods. For a successful operation, it is required to diagnose the disease preoperatively and to determine whether the disease spreads locally or extensively and to plan the surgical removal of the tumor on the basis of such findings. In this paper, a 71-year-old patient with an incidental parathyroid carcinoma diagnosed in the early postoperative period following an emergent orthopedic operation was presented. The final diagnosis was determined after the histopathological examination of the parathyroid gland.

Keywords: Parathyroid carcinoma, hyperparathyroidism, surgery
\end{abstract}

Öz

Paratiroid kanseri nadir görülen ve ciddi hiperparatiroidi tablosu ile seyredebilen bir hastalıktır. Hastalığın ameliyat öncesi dönemde tanınması ve adenomdan ayırımının net olarak yapılması zordur. Paratiroid kanserlerinin tedavisi boyun eksplorasyonuyla birlikte tümör ve aynı taraftaki tiroid dokusunun tamamiyle alınmasını ve ek komşu lenf nodlarının çıkarılmasını kapsar. Başarılı bir cerrahi girişim için en ideali, ameliyat öncesi dönemde tanı konulup hastalığın yerel ve uzak yayılım yapıp yapmadığını belirleyebilmek ve cerrahi çıkarımı ona göre planlamaktır. Bu yazıda, acil ortopedik cerrahi sonrası erken dönemde saptanan, 71 yaşındaki bir rastlantısal paratiroid karsinom olgusu sunuldu. Hastada kesin tanı postoperatif histopatolojik inceleme ile konuldu.

Anahtar Kelimeler: Paratiroid kanseri, hiperparatiroidizm, cerrahi
${ }^{1}$ Health Sciences University Mehmet Akif İnan Training and Research Hospital Clinic of General Surgery, Şanlıurfa, Turkey. Sağlık Bilimleri Üniversitesi Mehmet Akif İnan Eğitim ve Araștırma Hastanesi, Genel Cerrahi Kliniği, Şanlıurfa, Türkiye.

${ }^{2}$ Karamürsel State Hospital Clinic of General Surgery, Kocaeli, Turkey.

Karamürsel Devlet Hastanesi Genel Cerrahi

Kliniği, Kocaeli, Türkiye.

${ }^{3}$ Health Sciences University Mehmet Akif İnan Training and Research Hospital Clinic of Pathology, Şanlıurfa, Turkey. Sağlık Bilimleri Üniversitesi Mehmet Akif İnan Eğitim ve Araştırma Hastanesi, Patoloji Kliniği, Şanlıurfa, Türkiye.

Çıkar Çatı̧̧ması: Yazarlar çıkar çatışması bildirmemişlerdir.

Conflict of Interest: No conflict of interest was declared by the authors.

Finansal Destek: Yazarlar bu olgu için finansal destek almadıklarını beyan etmişlerdir.

Financial Disclosure: The authors declared that this case has received no financial support.

Geliş Tarihi / Received

09.08.2017

Kabul Tarihi / Accepted

11.09.2017

Yayın Tarihi / Published 01.12.2017

Sorumlu yazar / Corresponding author

Mehmet Tolga Kafadar MD

Health Sciences University Mehmet Akif İnan Training and Research Hospital, Clinic of General Surgery

Esentepe Mahallesi Ertuğrul Caddesi 63300, Şanlurfa, Turkey

Tel: + 904143186000

Fax: + 904143186707

E-posta: drtolgakafadar@hotmail.com

Copyright 2017 ACEM

\section{Introduction}

Parathyroid cancer is detected in 1-3\% of all primary hyperparathyroidism cases. While some serious clinical situations such as kidney disease, bone disease and hypercalcemic crisis can be observed during the diagnosis, some patients may not have any symptom [1]. It is generally hard to determine the diagnosis before or during the operation and due to insufficient surgery, it also possible to observe mortality with recurrences, local invasions, distant organ metastasis and hypercalcemic crisis [2]. In this paper, a geriatric patient with parathyroid carcinoma was presented as a rare cause of the hyperparathyroidism. 


\section{Case Report}

A female patient who was seventy one years old with the complaint of a fracture on the right intertrochanteric femur was taken into an emergent operation by the orthopedic clinic. The patient had no background disease other than diabetes mellitus. After the surgery in the early follow up period, hypercalcemia (serum calcium $(\mathrm{Ca})=17 \mathrm{mg} / \mathrm{dL}$ ) was diagnosed and value of parathormone (PTH) was $2586 \mathrm{pg} / \mathrm{dl}$. In physical examination of the patient, a hard, nodular and immobile mass with a diameter of $3 \mathrm{~cm}$ was detected at the left inferior of the neck. The patient who was suspected with any kind of parathyroid pathology at the first time was observed by considering the thyroid nodule located at the left lobe of the thyroid gland which includes solid and cystic components with dimensions of $41 \times 37 \mathrm{~mm}$ at the thyroid ultrasound (US).In computed tomography of the neck, the lesion was shown to be connected with thyroid tissue at the inferior of the left thyroid lobe with a diameter of $3 \times 4 \mathrm{~cm}$. Additionally, there were locally cystic areas and heterogeneous structure (Figure 1a-c). The observation was considered as parathyroid adenoma and it was reported that there is no lymph node on the neck.In the Tc99mpertechnetate thyroid scintigraphy, it was found a significant increased uptake concordant with toxic thyroid nodule with a dimension of nearly $36 \times 24 \mathrm{~mm}$ at the left inferior left lobe thyroid gland and it was also found that the ground activity was suppressed at the remaining thyroid gland.
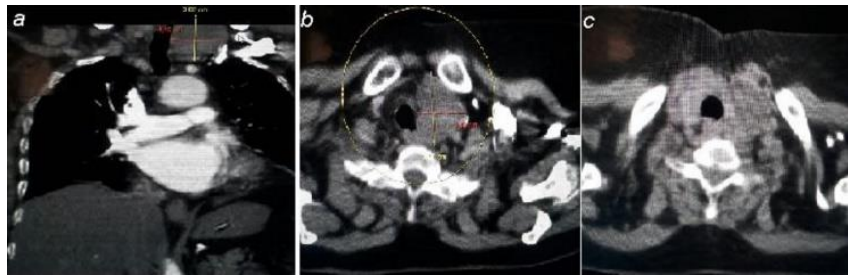

Figure 1. (a-c) The tomography image of the mass which is located in the inferior pole of the left lobe of the thyroid

During the early visualization which was performed with Tc99m-methoxyisobutylisonitrile (MIBI), a $3 \mathrm{~cm}$ nodular lesion with an increased activity uptake at the left lobe of the thyroid gland was observed. At the second hour, the uptake at the thyroid gland decreased significantly (washout) while the activity at the left lobe neighborhood of the nodular lesion maintained. At the whole abdomen US, a urinary stone with a diameter of $9 \mathrm{~mm}$ and $2.5 \mathrm{~cm}$ diameter para-pelvic cyst were found. With these findings, the patient was consulted with an endocrinologist and in order to control hypercalcemia, pre-operative hydration and bisphosphonate treatment were applied. After the completion of the required preparations, the patient was taken into operation with the preoperative diagnosis of parathyroid adenoma. A mass which was non-well circumscribed with a dimension of $3.5 \times 4$ $\mathrm{cm}$, locally adhered to the strap muscles of the thyroid, dirty brown colored and concordant with xanthic adenoma carcinoma was found at the inferior pole of the left lobe of the thyroid. By the reason that it was impossible to make a clear surgical boundary between the parenchymal thyroid tissue and the mass; the left thyroid lobe was taken out together with the mass. Due to consideration of the safety of the frozen section, intraoperative pathological analysis was not performed. Due to the fact that there was no lesion at the right thyroid lobe, no operation was applied to the right thyroid lobe. As the intact immunoreactivity PTH level decreased to $154 \mathrm{pg} / \mathrm{dL}$ intraoperatively after the excision; the operation was ended. During the follow up period, Ca level decreased to $9.8 \mathrm{mg} / \mathrm{dL}$ and the patient was taken to the routine follow-up and was discharged from the hospital in a healthy condition at the third day. Parathyroid carcinoma was reported after the post-operative histopathological examination (Figure 2a-c). A solid tumor with fibrosis invading surrounding tissues was observed, and atypical cells containing oval and clear cytoplasm were observed. Postoperative no adjuvant oncological treatment was given to the patient. $\mathrm{PTH}$, serum calcium and thyroid function tests were normal at the postoperative $3 \mathrm{rd}$ week follow up.

Serum calcium level and PTH values decreased to the normal levels and there was no uptake at the technetium-99msestamibi scanning at the 6 months follow-up period.

Informed consent was obtained from the patient.
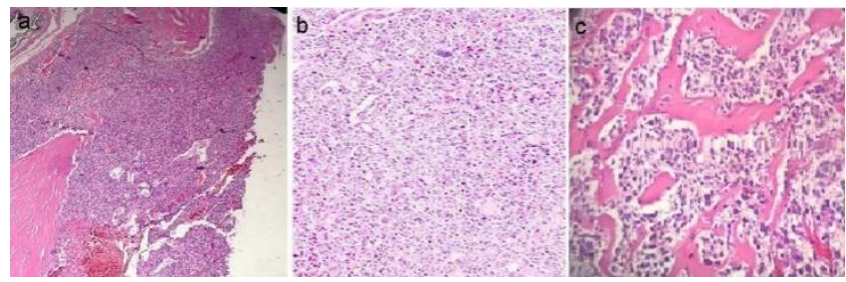

Figure 2. (a) Capsule invasion area at the tumor tissue (H\&E:4x) (b) The holes which are mostly constituted by essential cells between where the pleomorphic tumor cells are monitored (H\&E:40x) (c) The typical hyalinized fibrotic bands which are seen between the tumor cell holes (H\&E:40x)

\section{Discussion}

Parathyroid carcinoma is a rare clinical case. The calcium level increases (>14 mg/dL) and hypercalcemic crises can be observed at the parathyroid carcinoma like as in parathyroid adenoma and hyperplasia. PTH level may increase 40 times more than the normal level. However, the cases with normal laboratory findings are also reported. In a series with forty three cases, the average level of serum calcium was shown to be $14.6 \mathrm{mg} / \mathrm{dL}$ [3].

The parathyroid carcinoma is a disease which is mostly observed at the fourth decade and in male patients. This disease has no typical clinical findings. Complaints such as bulky mass on the neck, dysphagia, dyspnea and neck pain may arise. In addition to those complaints; some hypercalcemic findings such as nausea, vomiting, stomach pain, polyuria, bone and muscle pain, lethargy and constipation might also be observed at the hormone active parathyroid carcinoma patients [4].

The etiology of the parathyroid cancer is not known completely. Some sporadic cases are associated with radiation which is applied to the neck. Koea et al. [5] reports dominantly inherited familial hyperparathyroidism in association with parathyroid cancer with an incidence rate of $1.9 \%$ in the study which includes 358 patients. Furthermore, it has been reported that the parathyroid cancer can be observed at the cases of secondary or tertiary hyperparathyroidism which may rise due to end stage renal failure at the multiple endocrine neoplasia (MEN) I and IIA [6]. It is possible to monitor parathyroid carcinoma and to control whether there is an invasion to the surrounding tissues through imaging test which is performed before the operation. The neck US, computed tomography, magnetic resonance imaging, technetium-99mm-sestamibi scintigraphy and positron emission tomography can be used for that purpose. In a study which aims to diagnose all the parathyroid masses and includes 253 cases (the incidence rate of cancer is $2 \%$ ), it has been found that sensitivity of US is $82.9 \%$, sensitivity of scintigraphy is $83.6 \%$ and sensitivity of BT is $81.3 \%$ [7].

Needle aspiration biopsy is not recommended due to the risk of parathyromatosis and the seeding of the tumor cells at the needle line in patients who are considered as having parathyroid 
cancer before the operation. The frozen section examinations which are performed during the operation do not provide reliable information. The diagnostic criteria for the histopathological examinations were based on the criteria which were presented by the study of Schantz and Castleman [8] in 1973 which examines 70 patients. According to this study, the existence of capsular or vascular invasion, fibrous band, trabecular pattern and mitotic forms are considered as the diagnostic finding of parathyroid cancer.

Primary treatment for parathyroid carcinoma is surgical operation. It is required to control the hypercalcemic situation before the operation. Regardless of the existence of symptoms, hypercalcemia treatment is recommended if serum calcium concentration is $>14 \mathrm{mg} / \mathrm{dL}$. The recommended treatment for a patient with normo-calcemic situation, the parathyroid gland must be taken out with the thyroid lobe of the same side as en bloc. If there are any suspicious lymph nodes or invasion to the surrounding tissues, it is required to give effort to remove them. In cases with invasion of the recurrent laryngeal nerve, this nerve must be excised [1]. It has been found that in more than $50 \%$ of the patients who were applied parathyroidectomy and afterwards the parathyroid cancer was detected, recurrence develops. The recurrence rate is $10-33 \%$ for the patients with en bloc wide resection by considering parathyroid cancer before or during the operation [9]. The postoperative calcium follow-up should be done carefully after the surgery. Hypocalcemia might be observed temporarily after parathyroidectomy, if this situation lasts for long time, the hungry bone syndrome should be suspected [10].

Parathyroid cancer is slowly progressing disease and its prognosis might vary. Early diagnosis and total removal of the tumor markedly improve the prognosis. In patients with local recurrence and metastasis, the prognosis is poor. In cases where serum calcium levels do not decrease or higher calcium levels are detected in the follow-up period, existence local recurrence or metastasis should be suspected. The metastasis generally progresses mainly towards to the lungs (40\%) and typically towards to the bones and the liver. Disease-free survival period after the metastasis is very short and deaths are usually associated with metabolic reasons [9]. While the time period between operation and recurrence is usually almost 3 years, there are some cases which are reported until 20 years. The 5-year and 10 -year survival rates are reported as $40-86 \%$ and $49 \%$ respectively [11].

Our case was diagnosed incidentally and en bloc resection with thyroidectomy was performed. The cure is considered due to the normal serum calcium levels and PTH values and no uptake found at the technetium-99m-sestamibi scanning as in the present case after the follow up at the postoperative sixth months.

In conclusion, parathyroid cancer is a rare disease which is difficult to diagnose and treat. The most appropriate treatment is extensive surgery and elimination of hypercalcemic findings. Surgical treatment should be planned by considering minimum recurrence. Final diagnosis should be determined through histopathological examinations.

\section{References}

1. Goswamy J, Lei M, Simo R. Parathyroid carcinoma. Curr Opin Otolaryngol Head Neck Surg 2016; 24: 155-62.

2. Cetani F, Pardi E, Marcocci C. Update on parathyroid carcinoma. J Endocrinol Invest 2016; 39: 595-606.

3. Wynne AG, van Heerden J, Carney JA, Fitzpatrick LA. Parathyroid carcinoma: clinical and pathologic features in 43 patients. Medicine (Baltimore) 1992; 71: 197-205.
4. Cao J, Chen C, Wang QL, Xu JJ, Ge MH. Parathyroid carcinoma: A report of six cases with a brief review of the literature. Oncol Lett 2015; 10: $3363-8$

5. Koea JB, Shaw JH. Parathyroid cancer: Biology and management. Surg Oncol 1999; 8: 155-65.

6. Kirkby-Bott J, Lewis P, Harmer CL, Smellie WJ. One stage treatment of parathyroid cancer. Eur J Surg Oncol 2005; 31: 78-83.

7. Lumachi F, Ermani M, Basso S, Zucchetta P, Borsato N, Favia G. Localization of parathyroid tumours in the minimally invasive era: which technique should be chosen? Population-based analysis of 253 patients undergoing parathyroidectomy and factors affecting parathyroid gland detection.Endocr Relat Cancer 2001; 8: 63-9.

8. McClenaghan F, Qureshi YA. Parathyroid cancer. Gland Surg 2015; 4: 329-38.

9. Snell SB, Gaar EE, Stevens SP, Flynn MB. Parathyroid cancer, a continued diagnostic and therapeutic dilemma: report of four cases and review of the literature. Am Surg 2003; 69: 711-6.

10. Tohme JF, Bilezikian JP. Hypocalcemic emergencies. Endocrinol Metab Clin North Am 1993; 22: 363-75.

11. Hundahl SA, Fleming ID, Fremgen AM, Menck HR. Two hundred eighty-six cases of parathyroid carcinoma treated in the U.S. between 1985-1995: A National Cancer Data Base Report. The American College of Surgeons Commission on Cancer and the American Cancer Society. Cancer 1999; 86: 538-44. 